\title{
IN SITU GEOTHERMAL ENERGY TECHNOLOGY: AN APPROACH FOR BUILDING CLEANER AND GREENER ENVIRONMENT
}

\author{
Md. Faruque Hossain ${ }^{1,2}$ \\ 1 Department of Civil and Urban Engineering, New York University, 6 Metro Tech, Brooklyn, New York \\ 11201, USA, e-mail: faruque55@aol.com \\ 2 Green Globe Technology, 4323 Colden Street 15L, Flushing, New York 11355, USA
}

Received: 2015.10.27

Accepted: 2015.12.09

Published: 2016.01.06

\begin{abstract}
Geothermal energy is abundant everywhere in the world. It certainly would be a great benefit for human being once it is produced by a sophisticated technology. Consequently, it would be the biggest console for earth considering environmental sustainability. Unfortunately, the current status of commercial production of geothermal energy primarily from hydrothermal, geopressured, hot dry rock, and magma are limited to a few countries due to technological difficulties and production cost. This paper describes a simple technology where an in situ geothermal plant assisted by a heat pump would act as a high-temperature production $\left(>150^{\circ} \mathrm{C}\right)$ to provide excellent capacity of energy generation. The issue related to costs is interestingly cheaper on production, comparing to other technologies, such as solar, hydro, wind, and traditional geothermal technology as described in this article. Therefore, it is suggested that heat pump assisted in situ geothermal energy sources has a great potentiality to be a prime energy source in near future. Since the technology has a number of positive characteristics (simple, safe, and provides continuous baseload, load following, or peaking capacity) and benign environmental attributes (zero emissions of $\mathrm{CO}_{2}, \mathrm{SO}_{\mathrm{x}}$, and $\mathrm{NO}_{\mathrm{x}}$ ), it certainly would be an interesting technology in both developed, and developing countries as an attractive option to produce clean energy to confirm a better environment.
\end{abstract}

Keywords: global warming, geothermal energy, construction cost reduction, environmental sustainability.

\section{INTRODUCTION}

Global environmental crisis has become severe since 1900's because of releasing billion tons of greenhouse gases $\left(\mathrm{CO}_{2}, \mathrm{CH}_{4}, \mathrm{~N}_{2} \mathrm{O}\right.$ etc.) emission every year from industries, due to utilizing conventional energy sources. It was estimated that $29 \%$ of 2014 global greenhouse gas emissions are caused by industries' using energy from combustion of fossil fuels [UNEP/ WMO 2011]. The estimate shows that global $\mathrm{CO}_{2}, \mathrm{CH}_{4}, \mathrm{~N}_{2} \mathrm{O}$ emissions from fossil fuels have significantly increased since year zero (0000). Emissions of $\mathrm{CO}_{2}$ increased by over two times between the year zero (275 ppm) and the year 1900 (550 ppm) and from there jumped at 2000 ppm at the year 2014 which is over seven times higher than the year of zero. Emissions of $\mathrm{CH}_{4}$ increased by over two and half times between the year zero (250 ppb) and the year 1900 (750 $\mathrm{ppb}$ ) and from there jumped at $1850 \mathrm{ppb}$ at the year 2014 which is seven times higher than the year of zero. $\mathrm{N}_{2} \mathrm{O}$ emissions increased by over two times between the year zero (260 ppb) and the year 1900 (520 ppb) and from there jumped at $1250 \mathrm{ppm}$ at the year 2014 which is near five times higher than the year of zero. These heat trapping gases are the derivative form of the traditional energy combustion, getting wholly depleted into radioactive form ${ }^{14} \mathrm{C}$ into the atmosphere resulting acceleration of global temperature wormer, melting polar ices, increasing 
water level and eventually changing the climate [Houghton 2008, Jansen et al. 2007].

The simple physics is that when sunlight reaches earth, it is absorbed (70\%) and reflected (30\%). Light-colored objects and surfaces, like snow and clouds, tend to reflect most sunlight, while darker objects and surfaces, like the ocean, forests, or soil, tend to absorb more sunlight. The term albedo refers to the amount of solar radiation reflected from an object or surface, often expressed as a percentage. In albedo $(100 \%)$ and in absorption the sun energy by planet also releases some $(20 \%)$ of the energy back into the atmosphere as heat (also called infrared radiation) [Hegerl et al. 2007, Moonsri et al. 2015]. Greenhouse gases (GHGs) like $\mathrm{N}_{2} \mathrm{O}$, carbon dioxide $\left(\mathrm{CO}_{2}\right)$, and methane $\left(\mathrm{CH}_{4}\right)$ absorb energy into the atmosphere, slowing or preventing the heat to reach the space to loss their heat. In this way, GHGs act like a blanket, making earth warmer results in climate change [NRC 2002, NRC 2010, Solomon et al. 2007].

The changing climate is thus impacting the global environment severely. In a broad ways such as causing flood or draught, the influence of agricultural crop yields, affect human health, and destroy ecosystems are causing due to climate change. Climate-related impacts are also occurring across the countries and across many sectors of our global economy [Department of Energy 2008, UNEP/WMO 2011].

So, what can we do since we are the first generation with the tools to see how global environmental system is running towards danger due to the industrial conventional energy consumption? At the same time, we are the last generation with opportunities to prevent these dangers. Indeed, we can individually do something great by applying cleaner energy sources such as in situ geothermal energy and collectively helping to create global view for the development of this technology for confirming a cleaner and greener earth.

\section{MATERIAL AND METHODS}

In this paper we explain the most economical in situ method of capturing the heat pressure of approximately $800 \mathrm{kpa}$ (energy demand of a standard size industry of 1000 peoples' working or living place) energy from geothermal sources. The application of heat pump is well examined [Moonsri et al. 2015] to produce hot water from a shallow well. In the present research, heat pump was used to enhance geothermal energy production. This technology seems to be simple to tap geothermal energy by using geothermal heat pumps [Department of Energy 2008]. It is to tap into naturally occurring "hydrothermal convection" systems, where cooler water seeps into Earth's crust, is heated up, and then rises to the surface [Katrin et al. 2013, Xianbiao et al. 2013]. We have focused how conveniently this heated water to be forced to come out the surface to capture steam and use it to drive electric generators to provide heating and cooling. This groundsource heat pump generates constant year-round temperature of about $10^{\circ} \mathrm{C}$ in just a few hundred feet below the ground's surface. Either air or antifreeze liquid is not necessary to be pumped through pipes that are buried underground, and re-circulated into the building. In summer, the liquid moves heat from the building into the ground. In winter, it does the opposite, providing pre-warmed air and water to the heating system of the building.

The following calculation and cost effective schematic diagram shows that the use of in situ ground-source heating and cooling is the simplest where a tube runs from the outside air, under the ground, and into a building's ventilation system which is more effective systems use to compressors and pumps as in electric air conditioning systems to maximize the heat transfer (Figure 1).

This simple system is referred to as a regenerative reheat cycle, and it was found that this system will result in excellent thermal efficiency of the power plant. Prior to doing this analysis we have sketched the complete cycle on a $P$ - $h$ diagram based on the pressure, temperature, and quality data presented on the system diagram (Figure 2).

On examining the $P$ - $h$ diagram plot we notice the following:

- A mass fraction of the steam y is tapped from the LP turbine at the turbine tap (t) such that maximizing it with (1-y) of the liquid water at station (6) will result in the fluid reaching a saturated liquid state at station (7).

- The feed water pump then pumps the liquid to station (8), thus saving a significant amount of heat from the steam generator in heating the fluid from station (8) to the turbine inlet at station (1). It is true that with a mass fraction of (1-y) there is lower power output due to a reduced mass flow rate 


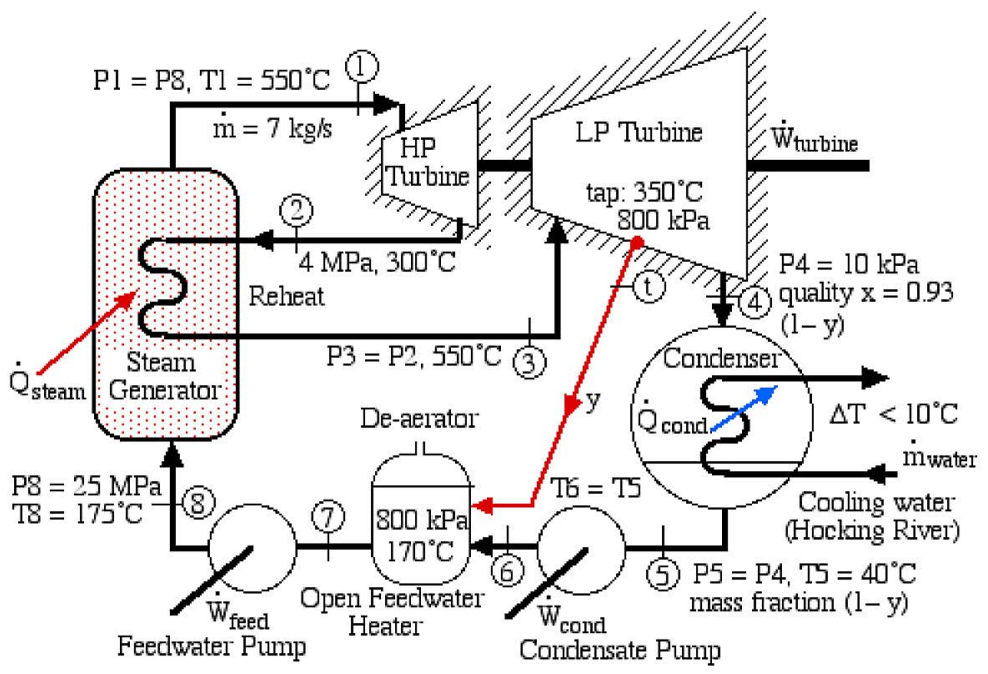

Figure 1. Schematic diagram the use of in situ ground-source heating and cooling

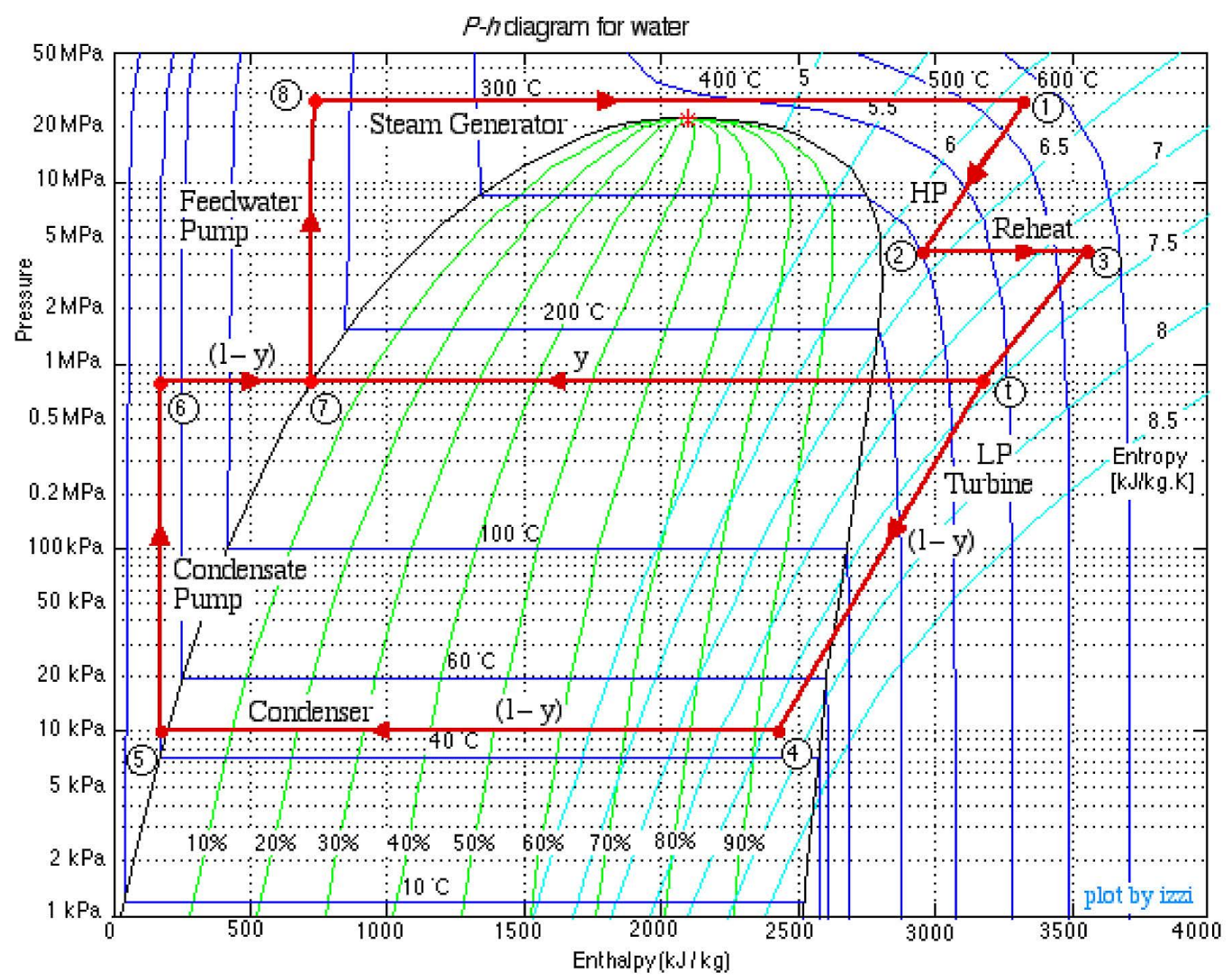

Figure 2. P-h diagram for water

in part of the LP turbine from the tap (t) to station (4), however, the following analysis shows that the net result is an increase in thermal efficiency.

Using the above-described methods for analysis of each component, as well as the steam tables for evaluating the enthalpy at the various stations (shown in red in Figures 3 to 6 ), and kinetic and potential energy effects, we determine the following:
1) Assuming that the open feed water heater is adiabatic, determine the mass fraction of steam $y$ required to be bled off the LP turbine which will bring the fluid from station (6) to a saturated liquid state in the de-aerator, where $y=0.18$ (Figure 3 ).

2) Assuming that both the condensate pump and the feed water pump are adiabatic, determine the power required to drive the two pumps (236 kW). 


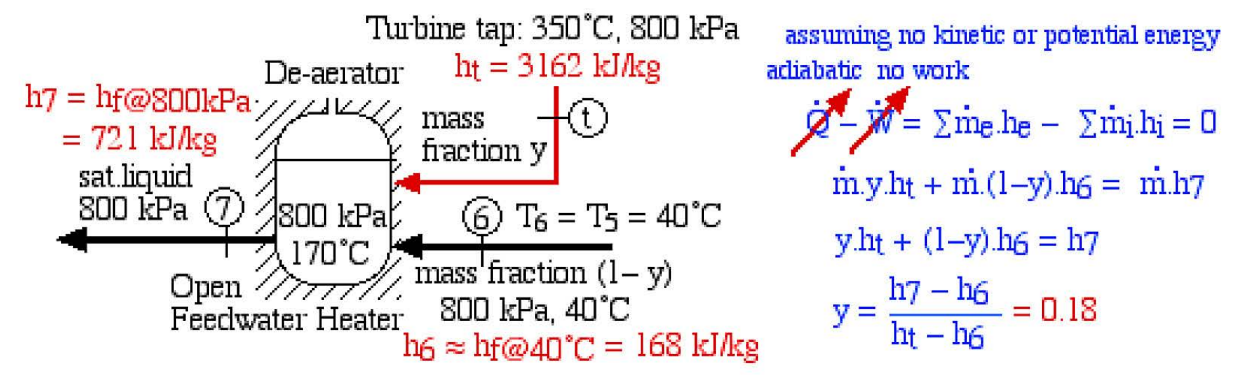

Figure 3. Adiabatic station

On examining the system diagram above we noticed something very interesting about the feed water pump. Until now we considered liquid water to be incompressible, thus pumping it to a higher pressure did not result in an increase of its temperature. However on a recent visit to the Gavin Power Plant we discovered that at $25 \mathrm{MPa}$ pressure and more than $100{ }^{\circ} \mathrm{C}$ water is no longer incompressible, and compression will always result in a temperature increase. We cannot use the simple incompressible liquid formula to determine pump work. However, we needed to evaluate the difference in enthalpy from the Compressed Liquid Water tables, leading to the following results (Figure 4).

3) Assuming that both turbines are adiabatic, we determined a new (reduced) combined power output of both turbines that the power output of the turbines was found to be 10.6 MW if no steam is bled from the LP turbine (9.65

\section{MW) - see Figure 5.}

Thus as expected we find that the net power output is slightly less than the previous system without the turbine tap. However power control is normally done by changing the feed water pump speed, and we normally find a liquid water storage tank associated with the de-aerator in order to accommodate the water mass flow rate. In our case, we simply need to increase the water mass flow rate from $7 \mathrm{~kg} / \mathrm{s}$ to $8 \mathrm{~kg} / \mathrm{s}$ in order to regain our original power output.

4) Determine the total heat transfer to the steam generator, including the reheat system (22.2 MW) - see Figure 6.

5) Determine the overall thermal efficiency of this power plant. Thermal efficiency ( $\eta$ th) is defined as the net work done (turbines, pumps) divided by the total heat supplied externally to the steam generator called cogeneration with the thermal efficiency of $42 \%$.

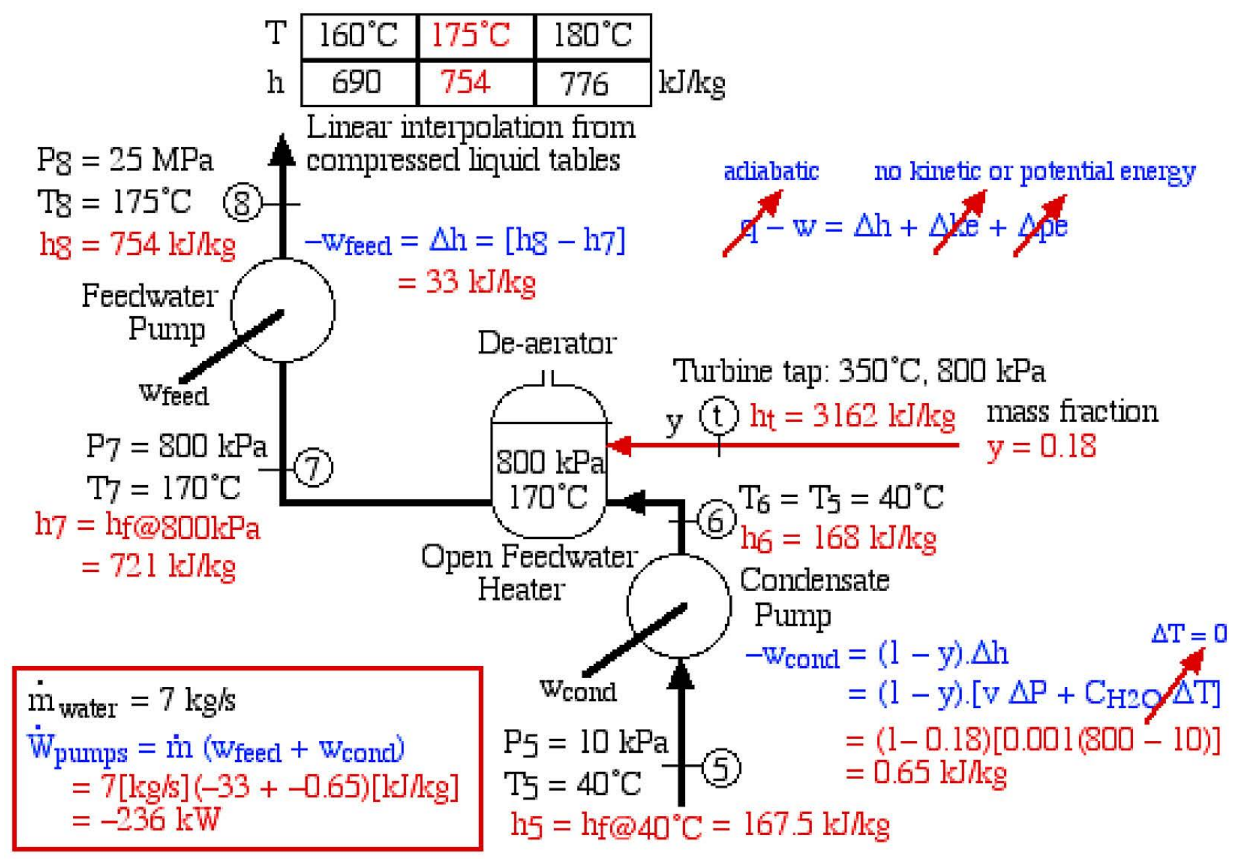

Figure 4. Compression station 


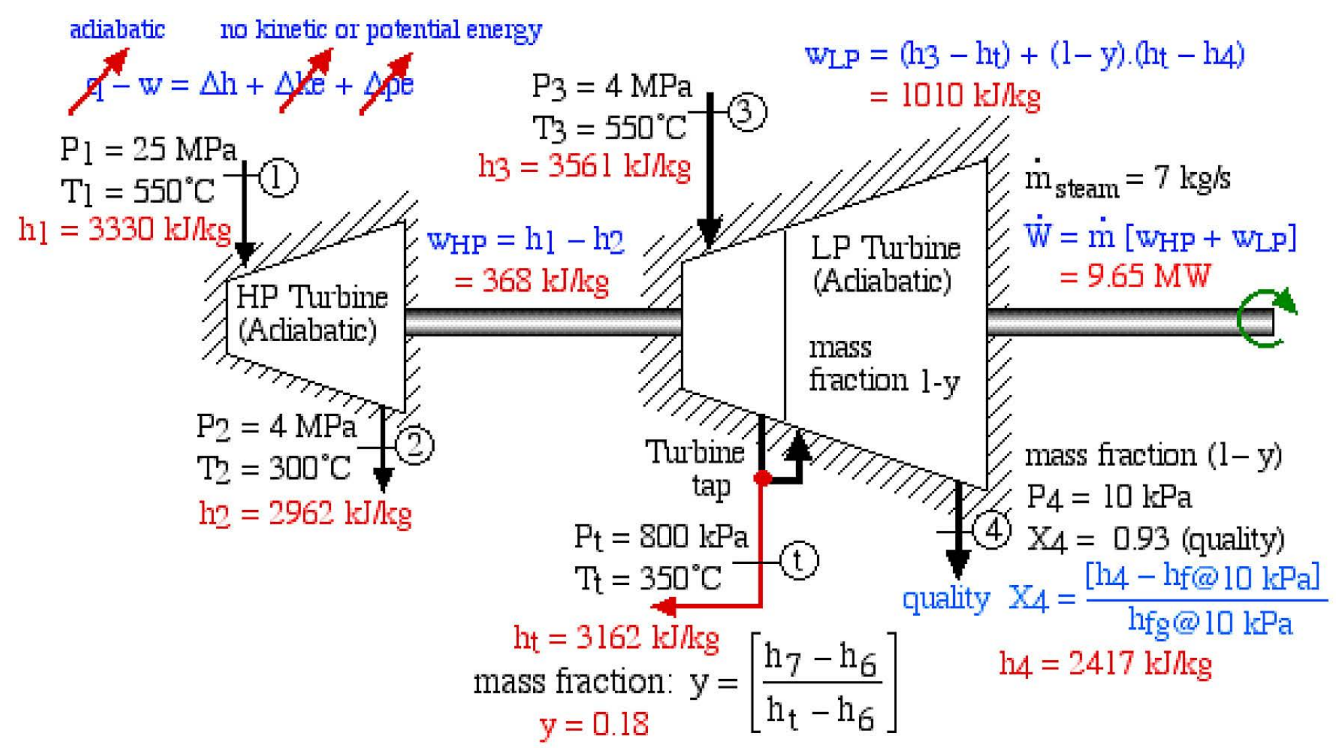

Figure 5. Combined station

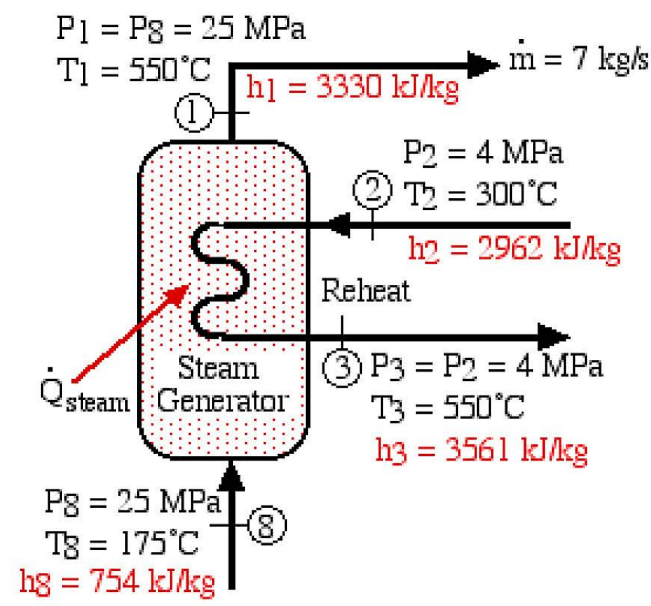

$$
\begin{aligned}
& \text { no work no kinetic or potential energy } \\
& \mathrm{q}-\mathrm{y} /=\Delta \mathrm{h}+\Delta \mathrm{e}+\Delta \mathrm{pe} \\
& \text { qsteam }=\Delta \mathrm{h}=(\mathrm{hl}-\mathrm{h} 8)+(\mathrm{h} 3-\mathrm{h} 2) \\
& =(2576+599) \mathrm{kJ} / \mathrm{kg} \\
& =3175 \mathrm{~kJ} / \mathrm{kg} \\
& \dot{\mathrm{Q}}_{\text {steam }}=\mathrm{m} \mathrm{qsteam} \\
& \quad=7[\mathrm{~kg} / \mathrm{s}](3175[\mathrm{~kJ} / \mathrm{kg}])=22.2 \mathrm{MW}
\end{aligned}
$$

Figure 6. Steam generator station

Thereafter, net energy (4.053 MW) production obtained from $800 \mathrm{kpa}$ (as in the above process) can be utilized for electricity generation for local buildings and industrial purposes to meet energy demand for a month for approximately 1000 people.

\section{RESULTS AND DISCUSSION}

U.S. Energy Information Administration (EIA) depicts the geothermal power is the only generation technology that has a Levelized Avoided Cost of Electricity (LACE) greater than levelized cost of electricity [Energy Technology Cost... 2010]. EIA also mentioned that the average net differences are negative for all technologies except geothermal, reflecting the fact that on average, new capacity is not needed by 2019. Geothermal in situ technology would be the only technology competitive in a system that has too much capacity or flat demand for new power plants as described above. It's important to note EIA's analysis includes the transmission and integration costs imposed by renewable technologies (Table 1).

It is the full economic potential of in situ geothermal resources can be represent an enormous source of electricity production. The U.S. National Renewable Energy Laboratory (NREL) found that geothermal sources around the world have a potential capacity of $3,800,000 \mathrm{MW}$, which could produce 30.8 billion MWh of electricity annually which is three times more than all of today's global electricity needs [U.S. Renewable Energy Technical Potentials... 2012].

Traditional geothermal power production is to be an expensive source of electricity since the 
Table 1. Transmission and integration costs of electricity imposed by renewable technologies

\begin{tabular}{|l|c|c|c|}
\hline \multicolumn{1}{|c|}{ Renewable technologies } & Transmission cost & Integration costs & Average \\
\hline Biogas & 5.94 & 6.82 & 6.98 \\
\hline Geothermal & 7.19 & 6.75 & $\mathbf{7 . 0 3}$ \\
\hline Wind & 8.40 & 9.77 & 8.68 \\
\hline Small Hydro & 8.72 & 8.91 & 8.66 \\
\hline Solar Thermal & 14.23 & 13.48 & 13.52 \\
\hline Solar PV & 15.18 & 11.90 & 13.96 \\
\hline UOG Solar PV & 16.21 & 47.00 & 21.65 \\
\hline
\end{tabular}

plant requires a significant amount of start-up capital in the earliest phases of exploration, the overall capital costs and operating costs of are significantly high. When looking at in situ geothermal power, interestingly, it is one of the most affordable and enduring technologies, comparing to other renewable technologies [Kolditz et al. 2013]. In addition, the geothermal plant has no fuel costs, and minimal maintenance or ancillary costs. Once a plant is operating it can generate electricity for 30 years or longer if the field is engineered and maintained sustainably [Energy Technology Cost 2010]. The costs for electricity from geothermal facilities are also becoming increasingly competitive. The U.S. Energy Information Administration (EIA) projected that the levelized cost of energy (LCOE) for new geothermal plants (coming online in 2019) will be less than 5 cents per kilowatt hour $(\mathrm{kWh})$, as opposed to more than 10 cents for new natural gas plants and more than 12 cents for new conventional coal [Annual Energy Outlook 2014]. Therefore, it indeed has the bright future to be used as primary source of energy production. The following estimate was performed at laboratory and revealed the details of cost comparison of conventional energy use and in situ geothermal energy use (Table 2).

In contrary, the total cost for 30 years energy consumption from a conventional source for a standard industry (1,000 people capacity) at $\$ 0.12 / \mathrm{kWh}$ of $4000 \mathrm{kWh}$ per month is $(30 \times 0.12 \times 4000 \times 12=\$ 172,800)$. This comparison between conventional energy use and in situ geothermal plant clearly indicate the cost saving of $\$ 44,400$ when in situ geothermal plant was used as the energy source.

\section{CONCLUSIONS}

Geothermal energy focuses on fundamental and applied research needed to deploy technologies to develop and integrate geothermal energy as one key element in the future energy portfolio [Kolditz et al. 2013]. For the safe, long-term operation of deep geothermal systems, we require a better understanding on the functioning of the geological gradient, mechanical, and biogeochemical conditions. Interestingly one of the unique aspects of geothermal heat is that it is found everywhere throughout the world. Call

Table 2. Cost of design and construction of an in situ geothermal plant and supply of its 30 years energy distribution

\begin{tabular}{|l|c|c|c|c|c|}
\hline \multicolumn{1}{|c|}{ List of component } & Materials cost & Labor cost & Equipment cost & GC \& OH cost & Total cost \\
\hline Drilling & $\$ 0$ & $\$ 3,000$ & $\$ 2,000$ & $\$ 1,000$ & $\$ 6,000$ \\
\hline Plants (800 kpa) & $\$ 25,000$ & $\$ 5,000$ & $\$ 1,500$ & $\$ 6,300$ & $\$ 37,800$ \\
\hline Instrumentation & $\$ 3,000$ & $\$ 1,000$ & $\$ 2,000$ & $\$ 1,200$ & $\$ 7,200$ \\
\hline $\begin{array}{l}\text { Electrical, mechanical and } \\
\text { plumbing control }\end{array}$ & $\$ 2,500$ & $\$ 1,000$ & $\$ 1,000$ & $\$ 900$ & $\$ 5,400$ \\
\hline $\begin{array}{l}\text { Supply for 30-years cost at } \\
\$ 0.05 / \mathrm{kWh} \text { for monthly 4000 kWh } \\
\text { for 1,000 people }\end{array}$ & \multicolumn{2}{|c|}{ Total cost } & & & $\$ 72,000$ \\
\hline \multicolumn{2}{|c|}{} & & & & $\$ 128,400$ \\
\hline
\end{tabular}

Note: This estimate was prepared by using current (July 2015) material cost from the top manufacturer and used internal union labor cost to install the materials as per standard engineering practice and construction production. The equipment rental was calculated as per current market rental cost in conjunction with production rate and critical path management schedule of the construction completion. 
it a "democratic" energy source that anyone can take advantage of, regardless of the conditions at the Earth's surface [Öhman et al. 2015, Tester et al. 2006]. Therefore, geothermal energy production in situ technology would not only be a convenient energy source it indeed would be also a great help for meeting climate change goals of COP 19. Since greenhouse gases rising sharply by utilizing traditional energy consumption, thus it is our ultimate option to use clean energy. Unlike other clean energy sources, such as wind and solar, in situ geothermal can provide consistent energy 24-hours a day, making it an appealing baseload replacement of other energy sources currently being consumed traditionally. High reliability and maintainability are required as a basic condition for the geothermal turbines and energetic components in order to provide a stable power supply [Buzăianu et al. 2015] where in situ geothermal technology would be a great option. The very best in situ geothermal plant indeed, therefore, play indispensable role to confirm cleaner and sustainable energy source for building a better earth.

\section{REFERENCES}

1. Annual Energy Outlook 2014. U.S. Energy Information Administration (EIA).

2. Breede K., Dzebisashvili K., Liu X., Falcone F. 2013. A systematic review of enhanced (or engineered) geothermal systems: past, present and future. Geothermal Energy, 1(4).

3. Buzăianu A., Moţoiu P., Csaki I., Popescu G., Ragnarstottir K., Guðlaugsson S., Guðmundsson D., Arnbjornsson A. 2015. Experiments on life cycle extensions of geothermal turbines by multi composite technology. Geothermics, 57, 1-7.

4. Department of Energy - Oak Ridge National Laboratory (ORNL) 2008. Geothermal (ground-source) heat pumps: market status, barriers to adoption, and actions to overcome barriers. Report ORNL/TM-2008/232.

5. Energy Technology Cost and Performance Data 2010. National Renewable Energy Laboratory (NREL).

6. Hegerl G.C., Zwiers F.W. , Braconnot P., Gillett N.P., Luo Y., Marengo Orsini J.A., Nicholls N., Penner J.E. and Stott P.A. 2007. Understanding and attributing climate change.

7. Houghton R.A. 2008. Carbon flux to the atmosphere from land-use changes: 1850-2005. In TRENDS: A Compendium of Data on Global Change. Carbon Dioxide Information Analysis Center, Oak Ridge National Laboratory, U.S. Department of Energy, Oak Ridge, Tenn., U.S.A.
8. Jansen E., Overpeck J., Briffa K.R., Duplessy J.-C., Joos F., Masson-Delmotte V., Olago D., Otto-Bliesner B., Peltier W.R., Rahmstorf S., Ramesh R., Raynaud D., Rind D., Solomina O., Villalba R., Zhang D. 2007. Paleoclimate. In: Climate change 2007: The physical science basis. Contribution of Working Group I to the Fourth Assessment Report of the Intergovernmental Panel on Climate Change. Cambridge University Press, United Kingdom and New York, USA.

9. Kolditz O., Jakobs L.A., Huenges E., Kohl T. 2013. Geothermal energy: A glimpse at the state of the field and an introduction to the journal Geothermal Energy, 1(1).

10. Moonsri P., Kunchornrat J., and Namprakai P. 2015. Hybrid energy thermal water pump for producing hot water from a shallow well Thailand. J. Energy Eng., doi: 10.1061/(ASCE)EY.19437897.0000278,0415023.

11. NRC 2002. Abrupt climate Change: Inevitable surprises. National Research Council. The National Academies Press, Washington, DC, USA.

12. NRC 2010. Advancing the science of climate change. National Research Council. The National Academies Press, Washington, DC, USA.

13. Öhman H. and Lundqvist P. 2014. Thermodynamic pre-determination of power generation potential in geothermal low-temperature applications. Geothermal Energy, 2(4), doi: 10.1186/s40517014-0004-2.

14. Solomon, S., Qin D., Manning M., Alley R.B., Berntsen T., Bindoff N.L., Chen Z., Chidthaisong A., Gregory J.M., Hegerl G.C., Heimann M., Hewitson B., Hoskins B.J., Joos F., Jouzel J., Kattsov V., Lohmann U., Matsuno T., Molina M., Nicholls N., Overpeck J., Raga G., Ramaswamy V., Ren J., Rusticucci M., Somerville R., Stocker T.F., Whetton P., Wood R.A., Wratt D. 2007. Technical summary. In: Climate change 2007: The physical science basis. Contribution of Working Group I to the Fourth Assessment Report of the Intergovernmental Panel on Climate Change. Cambridge University Press, United Kingdom and New York, NY, USA.

15. Tester J. et al. 2006. The future of geothermal energy: impact of enhanced. Massachusetts Institute of Technology and Idaho National Laboratory.

16. U.S. Renewable Energy Technical Potentials: A GIS-Based Analysis. 2012. National Renewable Energy Laboratory (NREL).

17. UNEP/WMO 2011. Integrated assessment of black carbon and tropospheric ozone: summary for decision makers. United Nations Environmental Program and the World Meteorological Society.

18. Xianbiao Bu, Lingbao Wang, Huashan Li 2013. Performance analysis and working fluid selection for geothermal energy-powered organic Rankinevapor compression air conditioning. Geothermal Energy, 1(2). 